\title{
北海道太平洋岸地域で発生した河川津波に伴う漂流水板の寸法計測

\author{
Measuring the Sizes of Drifting Ice Floes Caused by Tsunami Propagating up the Rivers in \\ Pacific Coastal Areas of Hokkaido
}

\author{
阿部孝章 $^{1}$. 吉川泰弘 ${ }^{2}$. 平井康幸 ${ }^{3}$ \\ Takaaki ABE, Yasuhiro YOSHIKAWA and Yasuyuki HIRAI
}

\begin{abstract}
In Hokkaido, Northern Japan, the tsunami of 2011 Tohoku Pacific-Coast Earthquake broke river ice and transported thousands of meter-long ice floes in rivers whose mouths are on the Pacific Coast. The objectives of this study are to investigate sizes and areas of ice floes by using photographs obtained during the field survey conducted after the tsunami and, on that basis, to estimate the masses of floes transported by the tsunami. Sizes and areas of them were measured using an image analysis technique and ice thicknesses are measured on site. In an extreme case, the estimated masses were approximately 1.2 to 20 ton on average and 5.0 to 170 ton as maximums of floes retained near the bridge piers. This work highlights the potential risks of ice floes, which can be hazardous to river structures such as bridge piers.
\end{abstract}

\section{1.はじめに}

2011年3月 11 日, 三陸沖を震源とした東北地方太平洋 沖地震が発生した。地震による被害に加え，東北地方で 発生した大津波により沿岸域のみならず河川域において 破堤や落橋, 氾濫等甚大な被害がもたらされた。世界的 にも, 予てから河川津波の危険性は指摘されていたが (田中ら，2006）, 今次津波を受け，河川施設に関しては 河川を逆流する津波の流体力を考慮して設計を行うこと と政府より提言された（河川津波対策検討会, 2011）.

一方で，この地震による津波は北海道の複数の 1 級河 川にも侵入が確認された（阿部ら，2012a）。12月から4 月は北海道における河川結水期間である. 地震直後に実 施した現地調査では，津波により破壊されたと考えられ る水板が漂流物化し, 河道内に多数堆積しているのが確 認された (阿部ら, 2012b).この結果は, 積雪寒冷地に おいては河川津波の流体力のみならず、漂流水板の衝突 力を考慮して施設設計を行うことが必要であることを示 唆するものである.しかし, 河川津波により破砕された 水板の質量や輸送速度が分かっていないため, 現状では 河川構造物に対する衝突力を評価することが非常に困難 である。

海洋域において, 流水は沿岸構造物に損傷劣化等の 様々な悪影響を及ぼすため, また, 地球規模での海水の

\begin{tabular}{lll}
\hline 1 正会員 & 修(農) & $\begin{array}{l}\text { (独法)土木研究所 } \\
\text { 寒地土木河川チー研究所 }\end{array}$ \\
2 正会員 & 博(工) & $\begin{array}{l}\text { (独法)土木研究所 } \\
\text { 寒地土木研究所 }\end{array}$ \\
3 正会員 & & $\begin{array}{l}\text { 北海道川開発局 札幌開発建設部 } \\
\text { 札幌河川事務所長 }\end{array}$
\end{tabular}

形成について現象を解明するため，そのサイズを計測す る試みは以前から国内外で行われている. 例えば, 衛星 画像，航空撮影写真等を用いた，Rothrockら (1984), Inoue ら (2004), そしてToyotaら（2006）によるものが ある.しかし, この種の解析手法は, 河川域において, 3 月という解水期に, 急速に融解する氷板津波痕跡につ いて適用することは, 時空間的に対象とするスケールが 異なるため困難である.

河川内を漂流する結水の特性を把握する取り組みと して, 山地河川で解水期に流下する巨大水板の挙動に 関する検討もなされているが (Jasek, 2003), 流量と気 温上昇により流下する漂流水板を扱ったものであり, 河川津波で破壊された水に同様の手法を適用するのは 困難である。寒冷地域である北米において、移動する 結水が構造物に加える負荷を検討した例（Johnstonら， 1999）もあるが，これも津波により破壊・漂流する氷 を対象とはしていない。河川津波による漂流水板の規 模や質量を定量的に評価した例は既往研究では見られ ないのが現状である.

以上の背景から, 本研究では河川津波に伴う漂流水板 による構造物への衝突力評価を行うための前段階とし て, 河川津波による漂流水板の質量を評価することを目 的とした。そのためにまず，津波来襲後河道内に滞留・ 堆積していた氷板痕跡の写真から画像解析手法により水 板の長辺及び面積を明らかにした．続いて質量を推定す るために現地で計測された氷板厚のデータから, 痕跡水 板の厚さを推定した。これらの結果から水板の質量を簡 易的に推定した。 


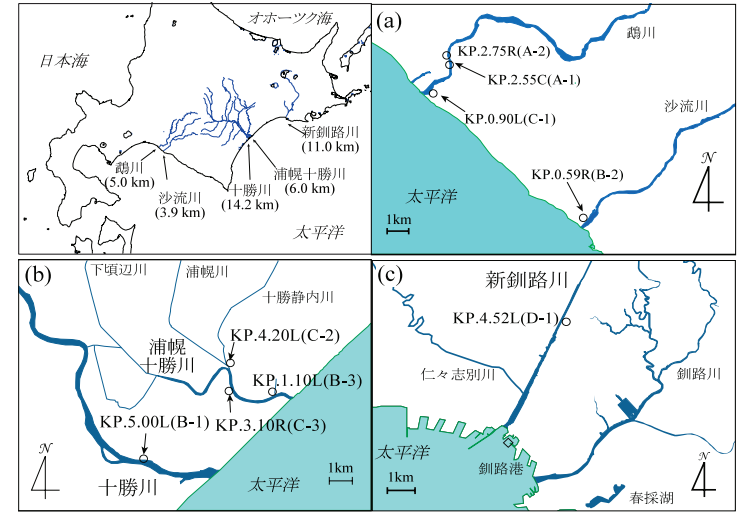

図-1 本研究の対象河川

(左上図括弧内は河川津波の遡上距離)

\section{2. 手法}

\section{(1) 現地調查}

本研究の調查対象流域は図-1 1 に示した北海道の太平洋 岸に位置する武川（むかわ），沙流川（さるがわ），十勝 川, 浦幌（うらほろ）十勝川, 新釧路川である. 著者ら は3 月 11 日の地震後, 北海道太平洋岸地域で津波注意報 が解除された後，複数班に分かれ，3月13日と14日の二 日間にかけて現地調査を実施した。

この当時，太平洋沖で余震が頻発していたため，低水 路近傍での詳細な調査は危険が伴うと判断された。そこ で，避難経路を確保しつつ安全かつ迅速に痕跡状況の概 略を把握するため，堤防上や高水敷上からの写真撮影を 行った. 写真の撮影位置を図-1 (a) 〜 (c) に○で示した. なお，本稿においてKP.の後に続く数值は河口からの距 離 $[\mathrm{km}]$ を表している.

\section{（2）調查写真の画像解析}

水板のサイズと面積を定量的に評価するため，画像解 析手法を次の二段階に分けて適用した。一つは，調査写 真から水板の最大長を計測し，堆積していた氷板サイズ について，各地点での傾向を把握することである．もう 一つは，漂流水板の面積を推定するため，痕跡調査写真 から水板の輪郭を抽出したものである.

氷板のサイズについては，以下の方法で計測した。ま ず図-2左に示したように，河川改修平面図CADデー夕上

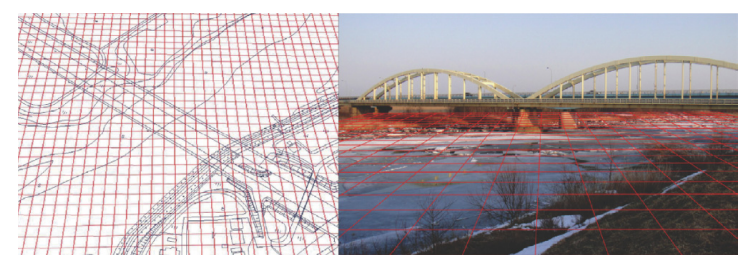

図-2 10mグリッドデータを重ね合わせた河川平面図及び調査 写真（いずれも鵡川KP.2.60鵡川橋地点）
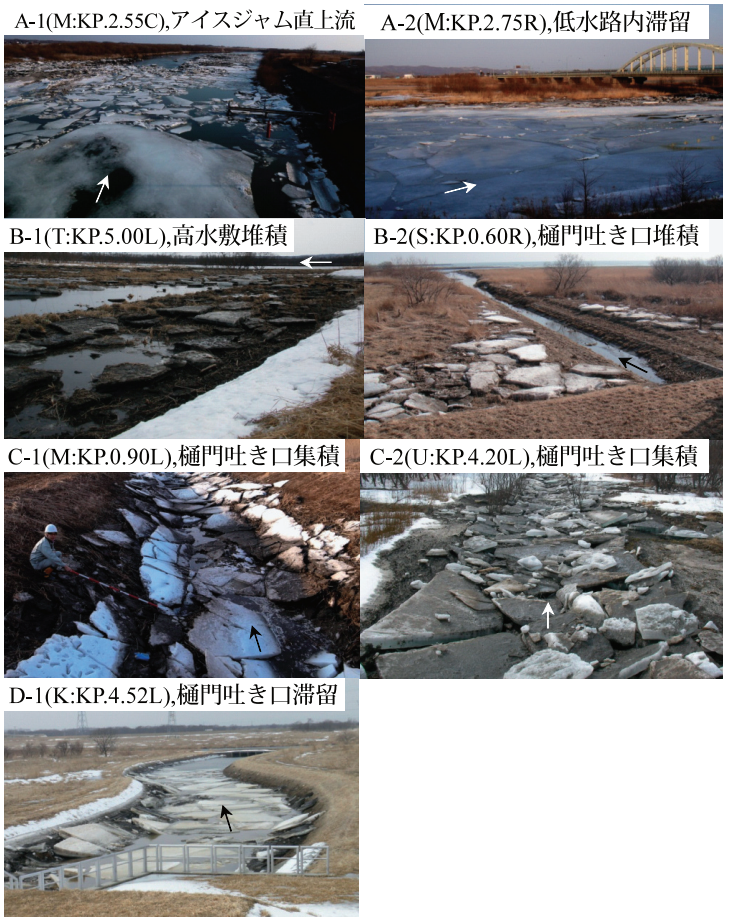

写真-1 水板痕跡調査の分類

(図中の黒または白の矢印は流向を表す)

に，格子状のグリッドデータを生成する。その上で，撮 影位置や撮影角度を考慮した上で，平面図の川幅，橋梁 位置等を基準にしてグリッドを傾斜させ，調査写真に重 ね合わせた（図-2右)。写真上で見た氷板輪郭の最も離 れた点同士を結ぶ線長 $L_{i \max }$ を氷板のサイズとした．現在 では痕跡が失われているため，本手法による誤差の定量 的評価は困難である。この事実を考慮し，本研究では川 幅や痕跡相互のサイズを比較するという目的に絞り，グ リッドとの相対的な大きさから，1m単位で計測した.

永板の面積については，上記と同様の手順でグリッド を写真に重敉合わせ，上面の輪郭が明瞭に抽出できる水 板について計測を行った，写真撮影により，痕跡を真上 から見た状態 (平面図) が写真内に投影された時，射影 変換が行われたと考えて，上述とは逆の手順で変換を施 して氷板輪郭とともにグリッドを平面図上に展開し，平 面図上での面積を計測した。

\section{3. 結果及び考察}

\section{(1) 現地調査結果}

本研究で実施した各河川における津波水板痕跡状況 を写真-1に示した．KP.の数值の後の L， C， R はそれぞ れ撮影位置が左岸側，河道内（橋梁上），右岸側を表し ている.なお，写真に付したA-1等の番号は撮影位置で, 図-1のそれと対応している。また簡単のため, 図表中 
表-1 氷板痕跡の主要な分類

\begin{tabular}{cc}
\hline タイプ & 特徵 \\
\hline $\mathrm{A}$ & 低水路における水板滞留 \\
$\mathrm{B}$ & 高水敷上に拉ける水板の散乱・堆積 \\
$\mathrm{C}$ & 吐き口水路における多数水板の集積 \\
$\mathrm{D}$ & 吐き口水路における摔留 \\
\hline
\end{tabular}

では河川を表す記号として武川は $\mathrm{M} ，$ 沙流川は $\mathrm{S} ， 十$ 勝 川は $\mathrm{T}$, 浦幌十勝川は $\mathrm{U}$, 新釧路川は $\mathrm{K}$ を用いることと する。

最上段の 2 枚の写真は鵡川のアイスジャム発生地点よ りやや上流の調查写真である. A-1 は KP.2.60 地点の鵡川 橋上から下流を撮影したものであり，KP.2.4付近で発生 したアイスジャム（水による河道閉塞）の概況を示す写 真である。鵡川では概ね KP.1.9〜2.5の右岸側，KP.2.4〜 2.7 の左岸側に砂州が形成されているが，撮影当時はいず れに打いても無数の水板が堆積していた．A-2はアイス ジャムょり 300mほど上流地点であり，低水路内に巨大 な氷板の滞留が確認された.

B-1 は十勝川に抢ける高水敷上の水板散乱の様子， B-2 は沙流川における樋門吐き口周辺の写真である。これら の地点では, 高水敷上に多数の水板散乱が確認された. これらは高水敷上で，互いにほとんど重なり合うことな く堆積していたため, 河川津波の水位上昇によって漂流 し, 水位下降に従って堆積したと考えられた.

$\mathrm{C}-1$ は轴川の河口付近の樋門吐き口水路, C-2 は浦幌 十勝川の支川浦幌川に接続する樋門吐き口水路における 氷板痕跡である. B-1，2の痕跡と異なるのは，氷板が 何層にも重なって樋門吐き口水路の水面を覆うように堆 積している点である.この種の痕跡は結水時河川津波に 独特のものと言え, 最悪の場合は樋門ゲートの動作を阻 害することも考えられる. 今後, 樋門等のオートゲート 化が施される際にも, 寒冷地では留意すべき現象と言え よう.

D-1 は新釧路川 KP.4.5 地点の樋門吐き口水路の痕跡写 真である．新釧路川ではこの地点の久顕著な水板痕跡が 確認されたが，C-1，2 と異なり何層にも重なっている様 子ではない。これは，この吐き口水路と本川の合流部手 前に人道橋が掛けられており, そのピアが本川からの水 の侵入・流出を抑制したものと推察された.

以上の調查結果を概括すると, 北海道太平洋岸で確認 された氷板痕跡の分類は, 表-1のようにまとめられた. タイプ A は，写真 A-1，2のような水板の低水路内での滞 留である，A-1 は手前に巨大氷板が見られ，その周囲に やや小さい水板が滞留している. A-2 は大小様々な水板 が低水路を埋めるように滞留していた。タイプ B は水板 が高水敷上に散乱している痕跡で, 特に低水路の近くに
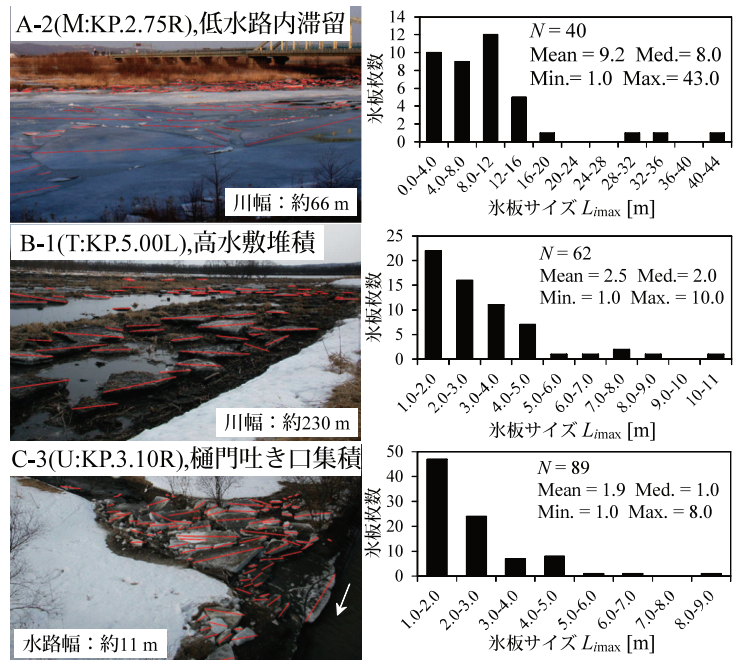

D-1(K:KP.4.52L),书門叶き口滞留 氷板サイズ $L_{i \max }[\mathrm{m}]$
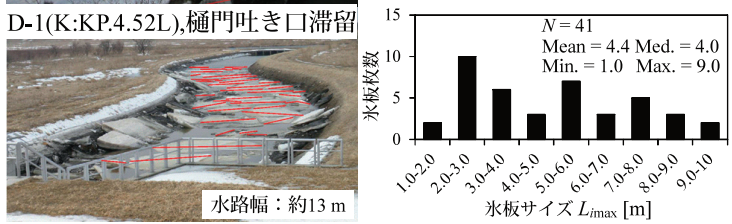

図-3 痕跡調查写真から抽出した痕跡氷板のサイズ（写真内 の赤線が氷板の $L_{i \max }$ を表し、右段のヒストグラムは各 区分の頻度を表す)

見られたものである. タイプCは, 多数水板が, 折り重 なるように樋門吐き口に集積した痕跡である.タイプD は, 新釧路川でのみ見られた吐き口水路における滞留で, 河川津波による水位上昇に伴い，亀裂が生じ，あまり相 対位置を変化させずその場に滞留したと推定されるもの で, 発生メカニズムの観点では夕イプ $\mathrm{A}$ の痕跡に近いと 考えられる。

\section{(2) 氷板痕跡の最大長 $L_{i m a x}$ 測定結果}

タイプ $\mathrm{A} \sim \mathrm{D}$ に分類された痕跡の調查写真に対し，画 像解析手法を適用し抽出した $L_{i \max }$ を図-3に示した。但し, ヒストグラム中の $N$ は抽出した氷板数, Mean, Med., Min., Max.はそれぞれ $L_{i \max }$ の平均值, 中央值, 最小值, そして最大值を表す。

最上段は鵡川 A-2 の写真から抽出したヒストグラムで ある。但し，ここでは低水路内の水板痕跡のみ抽出し， 砂州上の多数の痕跡は除いている. 最も頻度が大きいの は8.0〜 $12 \mathrm{~m}$ の区間であるが，計測の $L_{i \max }$ が $30 \mathrm{~m}$ を超え る氷板も存在する.この写真に写っているKP. 2.75 付近 を挟むKP.2.6，KP.2.8の横断面は，2009年の測量值で低 水路幅がそれぞれ $62,67 \mathrm{~m}$ である. $30 \mathrm{~m}$ を超える $L_{i \max }$ の 水板は, 河岸との接続と河川津波の水位上昇により, 最 大応力の発生するほぼ中央部分で結水が破壊され, 各々 のサイズとなったものと推定される.

B-1 及びC-3の写真は，それぞれ高水敷上に散乱，吐き 

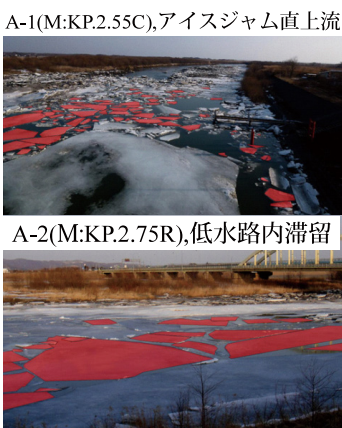

B-2(S:KP.0.60R),樋門吐き口堆積

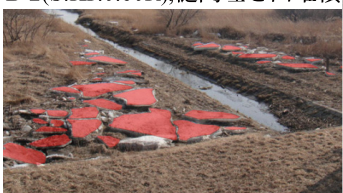

B-3(U:KP.1.15L), 高水敷堆積

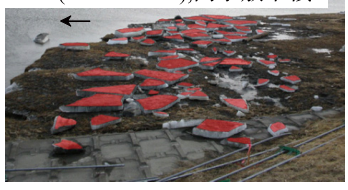

図-4 水板輪郭を抽出した調査写真, 及び，輪郭から計測し た面積のヒストグラム

口水路に集積した氷板痕跡で， $L_{i \max }$ のヒストグラムは指 数関数的に減少となった。これは, 堆積するまでに, 津 波の水位上昇により結水が破壊されてから, 漂流しなが ら河岸や植生と, あるいは相互に衝突することで更に小 さく破砕されたためと考えられた。漂流した時間, 距離 が長い程, 破砕の機会が増え, サイズは小さくなる傾向 にあると考えられる。

D-1の写真は，3.（1）節でも言及したように吐き口水 路内で破壊され, ほとんど位置を変えずに滞留した痕跡 と考えられた. $2.0 〜 3.0,5.0 \sim 6.0,7.0 \sim 8.0$ のつのピ ークを持つ分布となった. 調査時の水面幅は約 $13 \mathrm{~m}$ であ り, 中央の $5.0 \sim 6.0 \mathrm{~m}$ 区間のピークは前段落の議論と同 様に最大応力の発生点; 中央部分での破壊から説明され

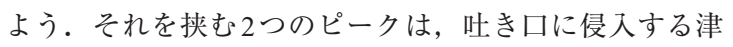
波フロントの波形勾配等, 他の要素が原因となった可能 性がある。

\section{（3）水板痕跡の面積 $A_{i}$ 測定結果及び質量の推定}

本節では, 顕著に氷板の滞留ないし漂流が確認された 䳒川・浦幌十勝川・沙流川の3 河川について, 代表的な 地点における氷板面積の計測結果を示す. 更に, 現地調 査時に実際に計測された氷板厚のデータから, 津波漂流 物としての氷板の質量を概算する.

図-4に示したのは，3河川において調査写真から抽出 した氷板上面の輪郭（塗り潰し部分）と，右段は輪郭に 基づき計測された面積のヒストグラムである。表-2に示
表-2 3 河川における承板厚 $h_{i}[\mathrm{~m}]$ の計測結果

\begin{tabular}{cccc}
\hline 河川 & 鴹川 & 沙流川 & 浦幌十勝川 \\
\hline 調査日 & $3 / 13,14$ & $3 / 13$ & $3 / 14$ \\
$N$ & 18 & 3 & 6 \\
Mean & 0.24 & 0.22 & 0.33 \\
Med. & 0.22 & 0.20 & 0.35 \\
Max. & 0.40 & 0.35 & 0.48 \\
Min. & 0.15 & 0.10 & 0.19 \\
\hline
\end{tabular}

したのは，3河川の調査地点で，無作為に抽出した氷板 の厚さを表にまとめたものである.

図-4より, A-1 地点の滞留水板の面積は平均して $5.5 \mathrm{~m}^{2}$ であった．尚，写真最手前に滞留する巨大水板は輪郭が 写真外にも存在するため抽出していない. A-2 地点の滞 留水板の面積は中央值でも約 $50 \mathrm{~m}^{2}$, 最大で $800 \mathrm{~m}^{2}$ を超え た. B-2, B-3 地点の写真については, 面積平均值は 1.7 $\mathrm{m}^{2}, 4.4 \mathrm{~m}^{2}$ 程度であり, 䳒川の滞留水板に比較すると非 常に面積は小さい. しかしこれらの堆積水板は, 漂流と 衝突を繰り返した後にこれらの大きさとなったと考えら れ，津波による漂流開始時には更に大きい氷板であった 可能性もある.

以下では, 水板質量を推定するための $h_{i}$ の代表值とし て中央值を用いることとした。これは以下のような理 由による. 最小值では, 河道内で融解が進行していた と考えられる高流速部分等の水板厚を用いることとな る. また, 最大值では河岸部等の元来流速の小さい領 域での水板厚を用いることとなるためである。すなわ ち, 最小值や最大值を用いると, 漂流物群である水板 の質量を過小評価，あるいは過大評価する可能性があ つたためである。いずれの河川でも中央值と平均值の 差は $2 \mathrm{~cm}$ 程度であったが，上述のように局所的に大き い，あるいは小さい氷板厚の影響を除くため，3河川で 統一して中央值を用いた.

鵡川の場合は表-2の中央值を用いると, A-2 地点の滞 留水板について, 平均及び最大面積を持つ氷板の質量は それぞれ, 約 $21 \mathrm{t}, 170 \mathrm{t}$ と推定される.これは, 東北地方 において今次津波の漂流物として確認された車（約 1 $2 \mathrm{t}$ ), 漂流木（約 $0.1 \sim 1 \mathrm{t} ）$ に比較しても数十倍から数百 倍の質量で, 漁船等の船舶にも匹敵する質量である.

沙流川及び浦幌十勝川で確認された痕跡水板の質量に ついても， $h_{i}$ の中央值を用いて推定した。 その結果, A-1, 2 地点の滞留水板よりも面積が小さいとは言え, 沙流川 （B-2 地点）では平均で約 $0.4 \mathrm{t}$, 最大で約 $1.8 \mathrm{t}$, 浦幌十勝 川（B-3 地点）では平均で約 $0.5 \mathrm{t}$, 最大で約 $3.2 \mathrm{t}$ と推定さ れた。

河川結氷は, 寒冷地の気象条件により毎年形成される もので，ハード対策が困難であるという特性を持つ. 寒 
冷地の河口域において国道橋等の重要構造物の設計に際 し，津波漂流物の衝突を考慮する場合には特に留意すべ き結果と言える.

\section{4. まとめ}

本研究では, 2011 年東北地方太平洋沖地震津波によっ て破壊が生じた太平洋岸に河口を持つ河川の結水に関 し, 調査写真の画像解析に基づく氷板サイズ, 面積の計 測を行った. 更に画像解析と調査デー夕を基に津波侵入 に伴い発生した氷板の質量を実現象に基づき推定するこ とに成功した。

得られた結果として, 河川津波による滞留水板の質量 は武川橋周辺で平均值としては約 $1 \mathrm{t} \sim 20 \mathrm{t}$, 最大では $5 \mathrm{t} \sim$ 170t と推定された。これらが河川津波の表面流速により 輸送され, 仮に構造物等へ衝突が発生した場合, それは 構造物の設計に際して決して無視できない作用力である と言えよう。少なくとも今後は, 寒冷地域においては河 口付近の国道橋・鉄道橋等重要な構造物の設計に際して は河川津波による氷板衝突を考慮し, 衝撃を弱める緩衝 材等の対策を早急に施すことが望ましいと言える.

現在では氷板痕跡は消失しているため, 上記画像解析 手法による計測誤差を検証するための情報を再度収集す ることは, 非常に困難である. また, 本研究の検討では 簡易に推定することしかできなかった氷板厚も考慮に入 れ, 検討を行うことが本来望ましい. 更に, 水板のサイ ズを決定する要因となる波高等の津波外力, 構造物等と の衝突による水の破砕過程, 水の材料物性等を踏まえた 議論には至っていない. 以上の点について, 引き続き検 討していくこととしたい.

河川津波と河川結水の相互作用を考慮した構造物の設 計基準を定めるためには, 今後も同様の結水時河川津波 が発生した際の現地観測が非常に重要と言える. 本研究 で適用した一連の簡易推定手法を用いれば, 調査写真か ら生じた氷板痕跡の面積を計測し, 簡易に質量の評価を 行うことが可能である.

また, 本研究で対象としたのは主に低水路周辺で滞留 または堆積していた氷板である。本稿では触れなかった ものの, 樋門ゲートへの河川津波の衝突が映像で確認さ れている (阿部ら, 2012b). 樋門等の堤防内構造物は, 津波遡上の方向とは異なる角度で水板衝突が発生する懸
念があり, 今後水理実験や数值解析手法を併用し, 発生 外力の検討を進めていく予定である．以上のような知見 が蓄積されてゆけば, 積雪寒冷地域における河川津波特 性を考慮した, 安全な河川構造物の施設設計に貢献する ことが期待される.

謝辞：本研究の遂行にあたり, 国土交通省北海道開発局 室蘭, 带広, 釧路各開発建設部には河道諸元デー夕等を ご提供いただきました。また, 本研究の一部は文部科学 省科学研究費補助金基盤研究（B）（研究代表者：渡邊康 玄, 課題番号24360197）の補助を受けました。ここに記 して謝意を表します。また, 現地調査にご協力頂いた関 係各位にも謝意を表します。

\section{参 考 文 献}

阿部孝章, 吉川泰弘, 安田浩保, 平井康幸 (2012a)：2011年 東北地方太平洋沖地震に伴い発生した津波の北海道内に おける河川遡上, 土木学会論文集 B1 (水工学), Vol.68 (4), pp. I_1525 - I_1530.

阿部孝章, 吉川泰弘, 矢野雅昭, 永多朋紀, 稲垣達弘, 桃枝 英幸，村上泰啓，平井康幸 $(2012 b) ： 2011$ 年東北地方太 平洋沖地震により発生した津波の結水河川における遡上 状況及び氷板痕跡調査, 寒地土木研究所月報, No.705, pp. $20-30$.

河川津波対策検討会（2011）: 河川への遡上津波対策に関する 緊急提言，国土交通省報道発表資料，2011年 8 月，p. 1 .

田中仁, 中川一, 石野和男, 矢野真一郎, Bandara Nawarathna, 安田浩保, 渡邊康玄, 長谷川和義（2006）： スマトラ沖地震津波によるスリランカでの被害に関する 現地調査一河川被害を中心として一, 水工学論文集, 第 50 巻, pp. $577-582$.

Inoue, J., M. Wakatsuchi and Y. Fujiyoshi (2004): Ice floe distribution in the Sea of Okhotsk in the period when sea-ice extent is advancing, Geophysical Research Letters, Vol. 31, L20303, 4 p.

Jasek, M. (2003): Ice jam release surges, ice runs, and breaking fronts: field measurements, physical descriptions and research needs, Canadian Journal of Civil Engineering, Vol. 30, pp. 113 127.

Johnston, E., W. Timco and R. Frederking (1999): An overview of ice load measurements on bridge piers. Proceedings of the 10th Committee on River Ice Processes, pp. 290 - 302.

Rothrock, D. A. and A. S. Thorndike (1984): Measuring the sea ice floe size distribution, Journal of Geophysical Research, Vol.89, No.C4, pp. 6477 - 6486.

Toyota, T., S. Takatsuji and M. Nakayama (2006): Characteristics of sea ice floe size distribution in the seasonal ice zone, Geophysical Research Letters, Vol. 33, L02616, 4 p. 